\title{
The Other Writing: Iconic literacy and Situla Art in pre-Roman Veneto (Italy)
}

\author{
Elisa Perego \\ The British School at Rome and University College London
}

\begin{abstract}
Introduction
In this chapter I discuss the relationship between 'Situla Art' and alphabetic writing in the Italian region of Veneto, c.650-275 BC. 'Situla Art' refers to a metalworking tradition, with realistic images embossed and engraved on a range of bronze items, especially the bucket-shaped vessels known as 'situlae', which have come to designate the entire situla art phenomenon. By taking further the approach of Luca Zaghetto $(2002 ; 2006 ; 2007)$, who has suggested interpreting the iconographic motifs of this complex decorative technique as a real language, I adopt the concept of iconic literacy - the skill of producing and interpreting images - to compare the elaboration of situla art and traditional literacy in a crucial phase of development for Iron Age North-east Italy.

Importantly, the aim of the study is neither to demonstrate that situla art was structurally equivalent to alphabetic writing nor to delineate general differences and similarities in the logic of iconic and verbal literacy. Rather, following (a) recent developments in sociolinguistics that proposed breaking down the dichotomy between verbal and iconic literacies and (b) Brian Street's insights into literacy's social and ideological value (Street 1984), my analysis explores the socio-ritual similarities and differences existing between these two modes of communication by tackling the socio-cultural milieu that produced them.
\end{abstract}

\section{Background}

\section{Situla Art: Definition, diffusion and interpretation}

Situla art is a conventional phrase indicating an artistic and craft movement which spread between the $7^{\text {th }}$ and $3^{\text {rd }}$ centuries BC in the North Adriatic basin (Arte Situle 1961; Capuis 2001;

\section{How to cite this book chapter:}

Perego, E. 2013. The Other Writing: Iconic literacy and Situla Art in pre-Roman Veneto (Italy). In: Piquette, K. E. and Whitehouse, R. D. (eds.) Writing as Material Practice: Substance, surface and medium. Pp. 253-270. London: Ubiquity Press. DOI: http://dx.doi.org/10.5334/bai.m 


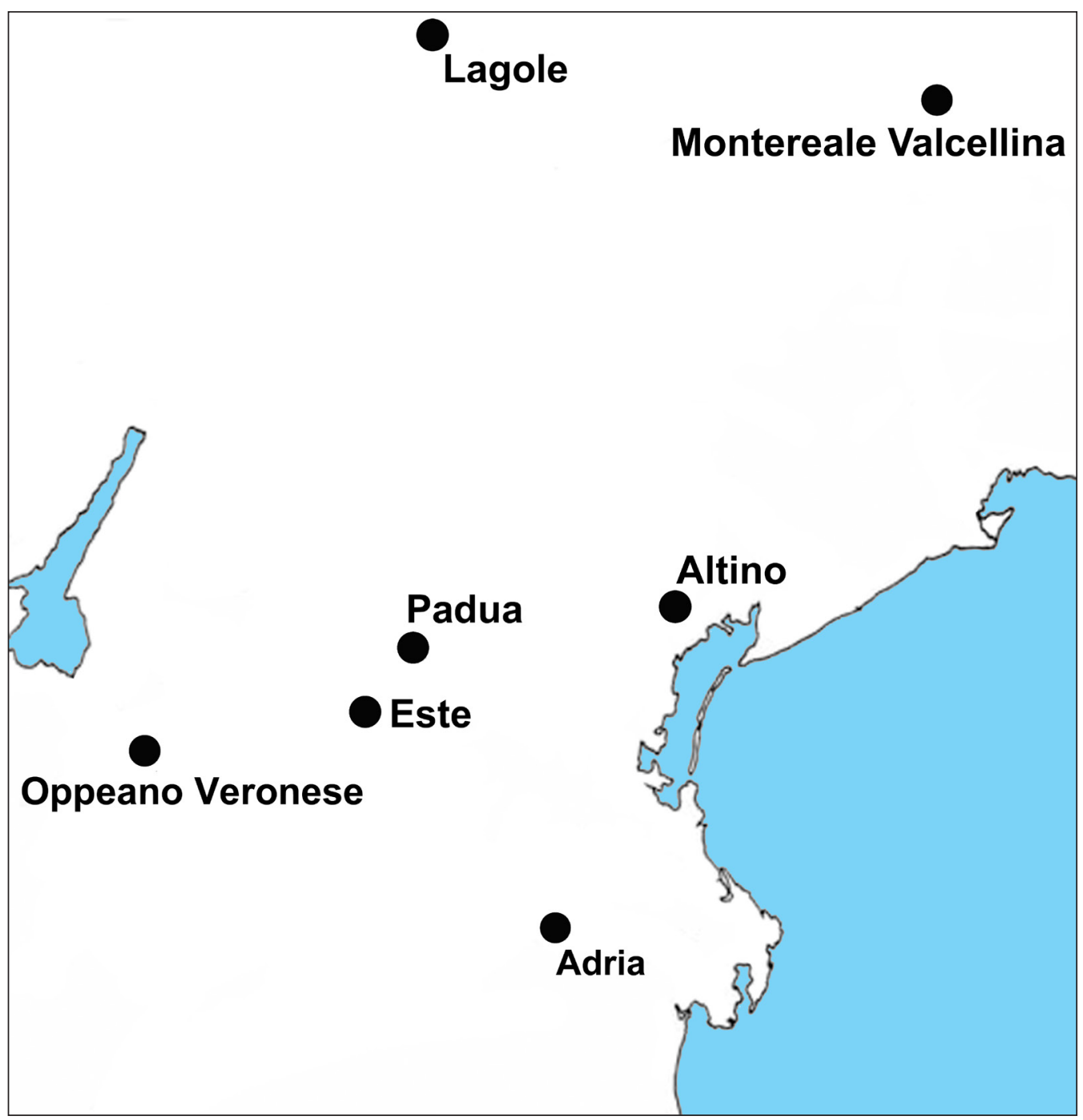

Figure 1: Map of Veneto with main sites mentioned in the text (drawn by the author).

Frey 1969; Lucke and Frey 1962; Zaghetto 2002; 2006; 2007; Figure 1). The artistic techniques of situla art entailed embossing and engraving realistic images on bronze items as diverse as lids, helmets, knife scabbards, belt plates, mirrors and vases. Approximately 150 decorated items have been recovered from the area located between the Po Valley and the Danube plain, including the central Alpine region, Slovenia and Lombardy. All these items have been generally recovered from graves, although the funerary context may have not been their primary destination. Other finds come from Bologna and the Ombrone Valley. In Veneto, situla art objects have been found in graves from both the main centres of Este and Padua and minor locations in the Veronese and the Piave Valley (Capuis 2001; Figure 1). The earliest Venetic examples of situla art come from Este and date to $650-625$ BC.

The situla art imagery is usually naturalistic and includes anthropomorphic motifs, everyday objects, animals and plants. Humans are involved in several different activities, including feasts, processions, warfare, hunting, farming, textile production, childbirth and intercourse (e.g. Capuis 


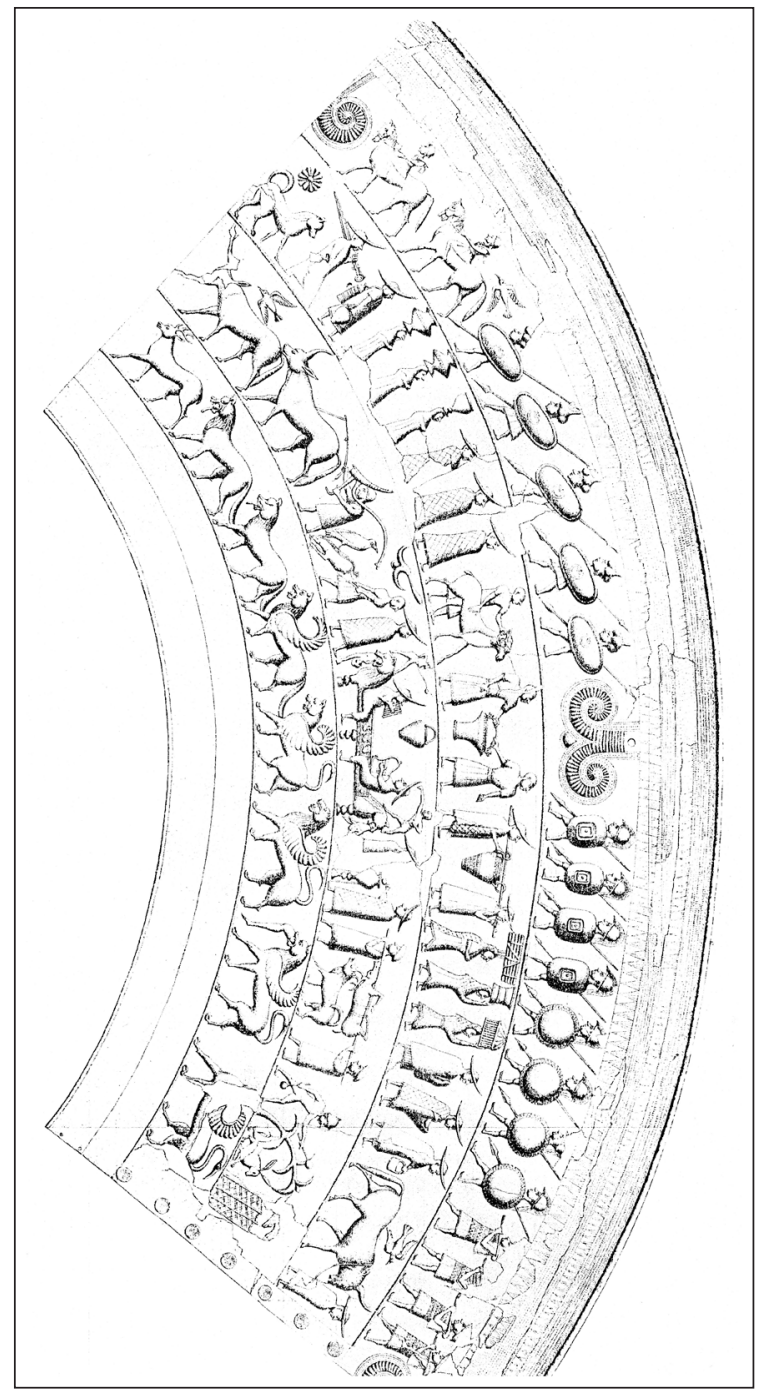

Figure 2: Reproduction of situla art motifs from the Certosa situla, Bologna (Lucke and Frey 1962).

2001; Gangemi 2008: 141; Zaghetto 2007). Objects include weapons, drinking implements, clothes and furniture. The faunal repertoire comprises both real animals and imaginary creatures such as winged lions. Each iconic element (human, animal, plant and objects) was arranged with others either in long bands of extreme complexity or in single scenes of limited extension - the former generally appearing on situlae (Figures 2-3), the latter on smaller items. While the complexity of the scene was probably influenced by the surface available, it remains possible that some motifs were chosen to appear on selected items for ideological reasons not always identifiable.

A major example of Venetic situla art is the situla recovered from Este Benvenuti tomb 126, c. 600 BC. On the Benvenuti situla, the narrative frame is arranged in three horizontal friezes running round the vessel's body on different levels (Capuis and Chieco Bianchi 1992: 74, 76-77). The first frieze features two drinking scenes with elite male drinkers, a man attending a horse, a boxing game and a procession of imaginary animals. The central frieze displays both fantastic and realistic animals accompanied by another man. The third frieze, just above the vessel's foot, features a 


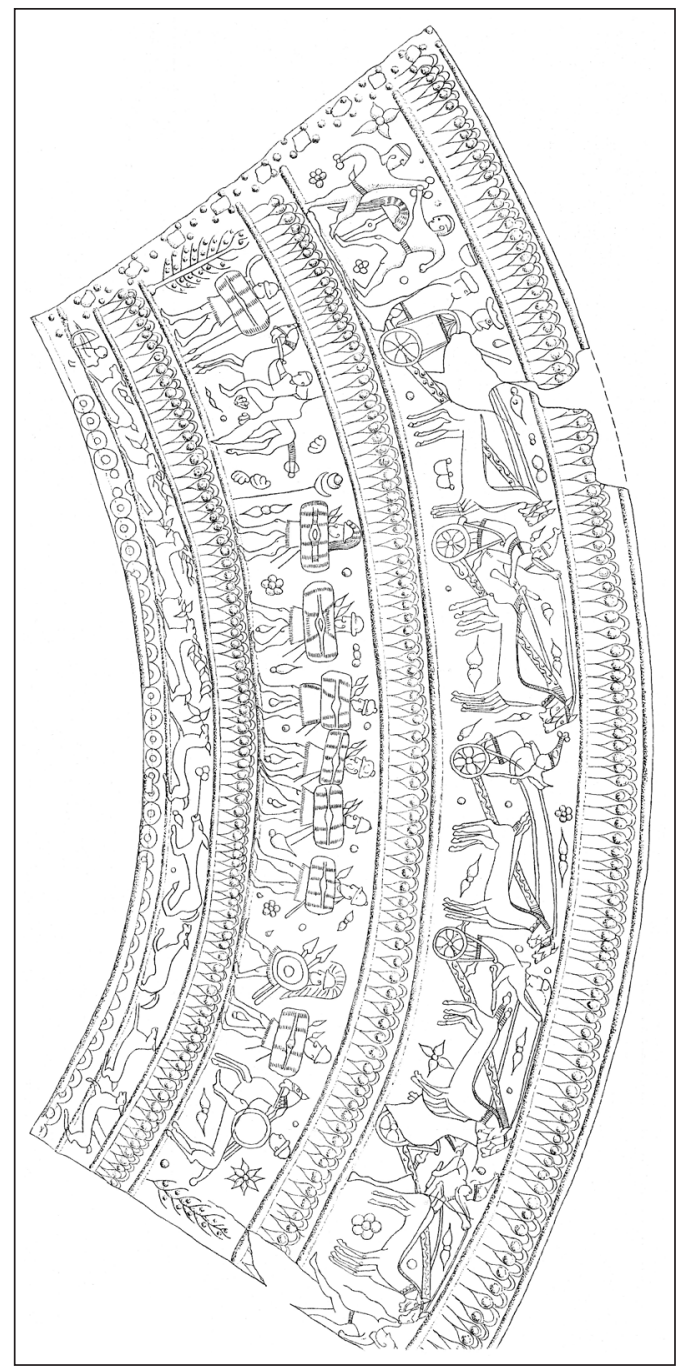

Figure 3: Reproduction of situla art motifs from the Arnoaldi situla, Bologna (Lucke and Frey 1962).

procession of both fully armed men and captives led by a charioteer; in a smaller scene, a warrior attacks a horn player. A minor example of Venetic situla art is the small symposium scene on the belt plaque from Este Carceri tomb 48, which I discuss below.

A repertoire of motifs similar to those of situla art is occasionally found on ceramic containers from Veneto (Capuis and Chieco Bianchi 1992: 81) and on some carved wooden chairs found in elite tombs of Central Italy, including the famous Tomba del Trono of Verucchio (von Eles 2002). The relation between situla art and these occurrences remains poorly understood. In Veneto, the production of decorated bronze items also included small votive laminas embossed and engraved with human or animal figures. These artefacts, however, are considered a different form of cultural manifestation in respect to situla art, especially because they have been found only in sanctuary contexts (Capuis 2001).

The origins and meaning of situla art are much debated (Arte Situle 1961; Capuis 2001; Frey 1969). Given the widespread adoption of iconographic motifs initially developed in the eastern 
Mediterranean, some scholars have advocated an 'oriental' origin for this artistic language (Di Filippo Balestrazzi 1967; 1980). Although this hypothesis is now outdated, an influence from the East is evident and may have spread in Italy through commercial contacts and the presence of foreign artisans (Capuis 2001: 201). The birth of situla art is now ascribed to $7^{\text {th }}$-century Etruria: local and / or foreign artisans would have then moved from Etruria to Bologna, and from there to Este and Slovenia (Capuis 2001: 200-201; Colonna 1980). Despite evidence for the development of this artistic tradition in time-space, the meaning of situla art remains unclear. The decorative motifs have been variously interpreted as:

- Generic reproductions of the mid- ${ }^{\text {st }}$ millennium aristocratic lifestyle;

- Representations of the afterlife;

- Evocations of myths connected with death, marriage and rebirth.

Nonetheless, several broader problems undermine these explanations, including the fact that no interpretation has provided a comprehensive explanation of the entire figurative system.

Recent research by Zaghetto $(2002$; 2006; 2007) has suggested interpreting the iconographic motifs of situla art as a real language, with its own rules which can be decoded on the basis of structural linguistics and semiotic approaches to reconstruct the whole meaning of the 'text'. From this perspective each iconic element (e.g. a hat) is considered as a word, while groups of related images (e.g. a procession) are equivalent to sentences, and the entire decorated object expresses the full meaning of a complete text, or a discourse, in which the individual elements are combined together to convey a message far more complex than the mere sum of its basic components. Another innovation of Zaghetto's analysis is the attention paid to the geographical and chronological distribution of the artefacts. Following a scrutiny of all the minor iconic elements (i.e. 'words' such as clothes) displayed on items from different locations and chronological periods, Zaghetto has suggested that each representation was probably deeply related to the cultural context in which the object was produced, if not a faithful depiction of real - or realistic - episodes of local life. In the case of the Benvenuti situla, for example, the drinking vessels on the first frieze clearly depict implements in use in $7^{\text {th }}$-century Veneto, including the situla itself. By contrast, the analysis of the 'sentences' has highlighted the existence of a recurring repertoire of scenes (e.g. 'the procession' and 'the lovemaking') probably referring to situations which held shared meaning for all 'consumers' of situla art, regardless of their language and ethnic origin. Situla art, therefore, has been interpreted as a means of communication developed to facilitate interaction between members of widely distributed elites unable to communicate verbally because they spoke different languages. This interpretation is strengthened by the adoption of some situla art items in international gift-exchange. An example is the Providence situla, originally produced in the Alpine region but found at Bologna and depicting a possible meeting between Etruscan and Alpine elite individuals (Zaghetto 2007: 180). The inscription found on the vessel, composed of Raetic or Alpine characters and written in a poor Etruscan language, clarifies that a 'community' donated the situla to a man.

In the case of the Castelvetro mirror, a detailed examination of each iconographic motif has allowed Zaghetto (2002: 40-41) to propose a convincing interpretation of the entire 'text'. The mirror includes three iconic panels. In panel one, a man sitting on a 'throne' is conversing with a veiled woman. This man indicates the number 'two' with his fingers. Nearby, a second woman is talking to another man. This woman indicates the number 'three' with her fingers. The second man wears a cap which is different in its shape and size from the larger hat worn by the 'enthroned' man. A careful analysis of the repertoire of clothing worn by figures in situla art has suggested that the adoption of different kinds of headgear probably indicated significant differences in social standing. The man with the large hat seated on the chair or throne, also a symbol of power, is probably an aristocrat, while the second man may have been a subordinate or the member of a 
lower social group. Panel two depicts a procession of three horses accompanied by three men, two of whom wear caps similar to that used by the 'low-class' man in panel one. On other situla art objects, similar processions of men and animals are generally associated with representations of sacrifice. According to Zaghetto, however, the Castelvetro procession is different, as it does not include the two characteristic images always associated with the ritual procession, namely the 'man who walks alone' and the 'sacrificial axe'. The meaning of the Castelvetro procession is clarified by panel three, which includes a couple making love on a couch. A second man wearing a large hat similar to that used by the enthroned individual observes the lovemaking. The scenes have been interpreted by Zaghetto as depicting the nuptial process. Panel one shows a discussion about the dowry, which is represented by the three horses in panel two. These are alluded to by the gesture of the woman in panel one, who indicates the number 'three', and are clearly led towards the lovemaking. The man with the large hat in panel three is possibly the same depicted enthroned in panel one, now attending the lovemaking as a witness of the nuptial agreement.

\section{Iron Age Veneto}

The following paragraphs offer a brief overview of Venetic social organisation, historical development and funerary ritual in order to introduce the context under study. This chapter focuses on selected evidence from the main Venetic settlement of Este, a choice motivated by the quality of the material available here, which surpasses that from any other Venetic centre excavated to date. A particular emphasis is given to the funerary evidence from the well-published BenvenutiRicovero cemetery (c.850-25 BC), a nucleus of around 300 tombs located in the Este Northern burial area (Bianchin Citton et al. 1998; Chieco Bianchi 1987; Chieco Bianchi and Calzavara Capuis 1985; 2006). This cemetery is notable for a concentration of exceptional written artefacts and situla art products and yielded some of the wealthiest graves ever unearthed in Veneto, proving that it was a privileged burial site for the Este elites over the entire Iron Age.

According to conventional Italian scholarship, during the Iron Age, Veneto was inhabited by a population of Indo-European origin - the Veneti of the Graeco-Roman tradition - which developed an increasingly complex and hierarchical society over the $1^{\text {st }}$ millennium (Capuis 2009; Capuis and Chieco Bianchi 1992; Prosdocimi 2002). The appearance of exceptionally wealthy graves during the $8^{\text {th }}$ century probably indicates the rise of local elites who reinforced their status through the acquisition, interment and probable pre-funerary display of exotica, bronze weaponry, precious ornaments and luxurious dining sets. Between the $7^{\text {th }}$ and $6^{\text {th }}$ centuries, Veneto's stronger involvement in the dense network of cultural exchanges between Italy, Continental Europe and the Mediterranean is revealed by larger imports of luxury goods and the adoption of situla art. The interaction with neighbouring populations, as well as internal growth, were among the factors which led to urbanisation, the adoption of writing and more structured rituals practised in sanctuaries. The significant involvement of Venetic elites in formalised cult practices is suggested by the abundance of bronze votive offerings at the main sanctuary sites (e.g. Ruta Serafini 2002). The development of Venetic society from the $5^{\text {th }}$ century remains partially obscure due to a lack of intact grave assemblages, although socio-political change might partially relate to the presumed penetration of large 'Celtic' groups in the Po Valley from c.400 вс (Gambacurta 2003). An increasing intervention of Rome in Veneto took place from the $2^{\text {nd }}$ century $\mathrm{BC}$, and led in approximately two centuries to the loss of Venetic language and material culture, as well as to the end of the local people's political independence (e.g. Cuscito 2009).

Evidence for Iron Age Venetic socio-political organisation remains scanty. Some information can be inferred from the Venetic inscriptions and funerary evidence (Capuis 2009; Perego $2012 a$ ). Already in the $9^{\text {th }}$ century Venetic society was probably structured around membership in kin groups, but over the following centuries it may have evolved toward a more articulated 
organisation of extended elite families and their subordinates. The erection of multiple family tombs in use for several generations is attested from the $3^{\text {rd }}$ century $\mathrm{BC}$ to the early Roman period (Balista and Ruta Serafini 1992; Capuis 2009).

Cremation is the main funerary ritual attested (e.g. Capuis 2009). Inhumation was also practised, but possibly for individuals belonging to marginal or non-elite social groups (Perego 2012a). As situla art products and funerary inscriptions come exclusively or almost exclusively from cremation graves, the latter are the focus of my analysis. Cremated remains were typically placed in cinerary vessels covered by a lid. It was not unusual to mingle the bones of multiple individuals in the same urn or to bury several urns in the same grave (Bianchin Citton et al. 1998; Perego $2012 a ; 2012 b$ ). At Este, urns were usually placed in stone containers, especially for rich burials. Grave goods such as ornaments and tools often accompanied the dead. Vessels and food were also placed in tombs, but generally outside the urn. The graves dramatically differed from each other in terms of wealth and ritual complexity. Non-elite tombs contained limited funerary equipment and were generally lacking in foreign goods. Conversely, elite graves contained up to hundreds of items and were characterised by exotica, lavish ornaments, bronze banqueting services, situlae, bronze belts, weaving implements, and, more rarely, situla art products, axes, inscribed objects and weapons (Bianchin Citton et al. 1998; Capuis 2009; Capuis and Chieco Bianchi 1992; Chieco Bianchi 1987; Chieco Bianchi and Calzavara Capuis 1985; 2006). Despite the evolution in shape / type of grave goods and the social changes occurring over time, $8^{\text {th }}-3^{\text {rd }}$ century вС Este elite tombs show the persistence of specific burial rites and grave-goods associations, suggesting the existence of a shared ritual language preserved until the late Iron Age.

\section{Literacy in Iron Age Veneto}

The extent of literacy in Iron Age Veneto is unknown. The number of inscriptions recovered so far amount to less than 1000 over a period of six centuries, but this may be a product of preservation if texts were also written on perishable items now vanished. Writing was possibly adopted from the Etruscans between the late $7^{\text {th }}$ and the first half of the $6^{\text {th }}$ century. The spread of alphabetic writing in Veneto, therefore, may be a few decades later than the introduction of situla art in the same region; the modalities of its introduction in Veneto, however, remain uncertain. A Greekmodified alphabet was used to write the local language, known as Venetic, an Indo-European idiom with similarities to Latin (Gamba et al. 2013; Marinetti 1992; 1999; 2004; 2008; Pellegrini and Prosdocimi 1967; Prosdocimi 1988; Whitehouse and Wilkins 2006).

Approximately 600 inscriptions have been published from different Venetic localities. The bulk of this documentation comes from Este (Marinetti 1992). Here, 250+ texts and pseudo-texts were unearthed in a single location, the sanctuary of Baratella, suggesting that writing was relevant to the cult. Other significant groups of inscriptions come the sanctuaries of Lagole in northern Veneto (c.100 inscriptions) and Altino Fornace near Venice (c.35-40) (Fogolari and Gambacurta 2001; Cresci Marrone and Tirelli 2009). Inscribed objects in smaller quantities derive from Padua (c.20) and many minor Venetic centres, which have generally produced no more than one to 10 inscriptions each (e.g. Marinetti 1999; 2004; Pellegrini and Prosdocimi 1967; Prosdocimi 1988). Several new inscriptions, however, have been recently recovered from settlements such as Oppeano and Montereale Valcellina (e.g. Marinetti 2008): the publication of this evidence, therefore, might modify the scenario outlined here.

The Venetic texts presently known are found on a wide range of stone, ceramic and metal artefacts, including gravestones, urns, drinking vessels, votive pedestals, laminas and metal reproductions of real writing implements. The bulk of the Venetic corpus comprises hundred poorly preserved texts or inscriptions consisting of single or repeated letters. The remaining dataset includes about 250 items bearing texts consisting of an average of 6-10 words. These texts usually 
carry female and male onomastic formulas. Verbs and nouns are rare. Votive texts may mention a divine name and a limited range of verbs probably meaning 'to give' or 'to offer', while epitaphs often include only the name of the deceased. A longer inscription ( $c .100$ words) has recently emerged at Este, proving that Venetic writing was put to more complex uses than previously supposed. The meaning of the inscription remains obscure although current scholarship interprets it as a ritual text or an inscription dealing with land and pasture management (Marinetti 1999; Whitehouse and Wilkins 2006).

Based on the evidence currently known, the context of use for writing in Iron Age Veneto may have mainly been limited to the ritual sphere. According to Whitehouse and Wilkins (2006: 533), most of the inscriptions dating to the $6^{\text {th }}-3^{\text {rd }}$ centuries BC $(351$ out of $466,75.3 \%)$ are votive in subject matter and come from sanctuary sites. Of the remaining 115, $72(15.4 \%)$ are from funerary contexts and have been found either on tombstones erected outside the grave or on small objects buried within the tomb. Another 25 (5.3\%) are probably funerary inscriptions as well, although their context of discovery is uncertain. Only rare texts are possible marks of ownership and an absolute minority (1\%) may have been public inscriptions. The bulk of the inscriptions dating between the late $3^{\text {rd }}$ century $\mathrm{BC}$ and the early Roman period $\left(c .1^{\text {st }}\right.$ century $\left.\mathrm{BC}\right)$ is still from sanctuary and funerary contexts, although the use of literacy partially changed, possibly in connection to Rome's expansion and the spread of Latin. Today, therefore, there is no clear evidence that Venetic writing was widely devoted to secular and daily uses or related to the practical functioning of the state (Whitehouse and Wilkins 2006: 534). Overall, the typology and contexts of deposition for $6^{\text {th }}-3^{\text {rd }}$ centuries BC inscriptions suggest that early literacy might have been mainly restricted to high-ranking individuals who adopted writing as a means of display in the ritual context (Lomas 2007). This seems confirmed by the relative scarcity of texts scratched on humble pottery vis-à-vis the relative abundance of inscriptions on more luxurious materials such as bronze and stone (for a similar discussion of Etruscan literacy, see Stoddart and Whitley 1988). Cornell (1991) offered an alternative account of the spread of literacy in ancient Italy by arguing for a more widespread competence even in non-elite contexts: the probable loss of most inscriptions on fragile materials may have prevented us from identifying non-elite forms of literacy. This latter possibility of poor preservation and the existence of biases towards elite and ritual writing cannot be discounted for Veneto as well: this is indeed suggested by the increasingly common discovery of brief inscriptions on pottery in settlement contexts (Marinetti 2008).

\section{Theory}

\section{Literacy and Communication}

In a narrow sense, literacy is often defined as the ability to read and write. This definition is usually applied to the Venetic context as well and has been adopted to frame my previous discussion of Venetic writing. Especially following recent technological developments, however, innovative research in anthropology, psycholinguistics and semiotics has promoted a wider adoption of the term 'literacy' to include the ability to use a wider array of media and modes of communication ranging from the internet to special systems of notation such as mathematical and musical notation systems (e.g. Buckingham 1993; Coiro et al. 2008; Gee 2008; Kress 2003; Selber 2004). In a broader sense, therefore, literacy can be defined as the recipient's awareness of the conventions which regulate the production, transmission and interpretation of any message, including for example emoticons, numeric codes, the mechanisms of video gaming, and the texts produced through microblogging and social networking. Verbal literacy implies the understanding and use of verbal messages (referring here to both speech and written texts) while iconic literacy entails the creation and comprehension of visual images (Kress 2003; Messaris and Moriarty 2005: 
481-482). Numerous visual communication studies have investigated the differences and similarities between writing, spoken language and the language of images, with divergent conclusions (e.g. Messaris 1994; 1997; Messaris and Moriarty 2005). A pitfall sometimes identifiable in these studies is that verbal and iconic modes of communication have been described and compared mainly in terms of their semantic and syntactic properties (Messaris 1997: viii), without fully exploring how the social context and the transposition of a message on a material support may influence people's understanding of the relation between images and words.

\section{The Materiality of Writing: Situla art and the Venetic script as social practices}

In this chapter I adopt the broader definition of literacy outlined above to compare the parallel development of Venetic writing and situla art at Iron Age Este. The relation between writing and iconography is explored by casting light on the social milieu in which people's engagement with situla art and written texts was constructed. Following Street's seminal volume on the social functioning and ideological value of literacy (Street 1984), research has suggested that literacy cannot be considered just as a set of technical skills, but as a historically situated social practice deeply embedded in socio-political dynamics. Literacy practices are meaningful and embedded in broader social goals and cultural practices; they are also patterned by power relations and social institutions and can be inferred from events mediated by literacy productions (in our case, for example, the rituals in which situla art objects were used). Literacy practices evolve over time and new ones are often acquired through processes of informal learning and sense making; furthermore, different literacies exist in associations with different domains of life: hence, some literacies are more dominant and visible than others (Barton and Hamilton 1998: 8).

From this perspective, both situla art and Venetic writing were entangled within the wider social background to which the entire Venetic communication system belonged. Issues of power negotiation and selected consumption according to the recipient's social standing pertain to all means of communication and become visible through the transposition of literacy practices into material form. Having taken material form, literacy practices may deeply impact even on people's embodiment and sensory perception, as I argue below. In this sense, both iconography and writing - as social and material products - share deep similarities of fundamental importance for this work.

Notably, the social milieu in which both situla art and writing were introduced probably consisted of various elite contexts. Ongoing contact with neighbouring populations offered Venetic dominant groups the opportunity to acquire novel techniques and materials to promote their prominence over commoners and competing peers. In this socio-political setting, it was not only writing and iconography that became means of status construction: this function must have been extended to all means of communication developing in the elite context, from the adoption of specific clothes to bodily gestures, which can be sometimes recovered through a scrutiny of the available material evidence. An example is offered by ritual drinking. The consumption and display of rare beverages and vessels by the Este elite was surely intended to convey a message (e.g. expression of wealth) which was also deeply entangled with high-ranking people's use of writing and situla art, as discussed below.

The creation of a sophisticated 'visual' language which implied the display of rare and often exotic implements such as luxurious ornaments, bronze banqueting sets, situla art products and inscriptions contributed to the construction of elite identities. When first introduced in Veneto, writing itself was possibly perceived and adopted in a similar way to iconography. As many were unable to read, the script may have essentially been a means of visual display, especially on monumental gravestones (Lomas 2007: 149-150). The exhibition of powerful status symbols was also 
accompanied by the elaboration of ritual practices including the consumption of sophisticated beverages at elite banquets and funerary ceremonies. People's awareness of the conventions governing the use and display of exotica and luxurious items, including situla art and early written objects (c.550-275 BC), was a form of literacy, in a broader sense. Being literate in this mainly visual language meant that the elites possessed adequate cultural knowledge to make sense not only of Venetic inscriptions and situla art motifs, but also of the messages encoded in the ritual gestures such as formal drinking both represented on situla art and practised in salient moments of their lives.

It is worth emphasising the strong corporeal overtones of this elite language, from the visual stimulation promoted by the brightness of polished bronze items to the tactile and visual engagements with the smoothness and luminescence of the rare colourful materials (e.g. glass and amber) used for lavish ornaments. Also rooted in bodily experience were eating practices such as meat consumption and the ingestion of alcohol, at the time presumably a rare and precious intoxicant, at least in its more sophisticated forms. The introduction and development in Veneto of these bodily practices and their representation in material forms must have promoted new elite forms of self-perception deeply rooted in high-ranking people's engagement with rituals, objects and foodstuffs probably not available to lower social strata.

\section{Analysis}

\section{Situla Art and Writing at Iron Age Este: Use, ritual, and display}

At Este, material supports for situla art included elaborate bronze belt plaques and lozenge-shaped belts, knife scabbards, large drinking and / or high-handled cups and situlae (Capuis and Chieco Bianchi 1992). Sympotic (i.e. related to the ritual consumption of sophisticated beverages, presumably including alcohol) implements such as situlae and drinking cups were also occasionally inscribed, although never when decorated with situla art, as discussed below. All the artefact types listed above acted as status symbols highly appreciated by the local elites, as their widespread deposition in prominent graves testifies. Moreover, the most luxurious drinking vessels, weaponry and belts were often exotic products, either as directly imported items or local reproductions of foreign models, a characteristic which probably increased their worth. The high symbolic value of these artefacts is further attested by the fact that they were not only used to carry the decoration but were also portrayed among the decorative motifs of situla art, thus constituting part of the situla art 'language' itself.

For example, situlae are commonly depicted on Venetic and non-Venetic situla art products as key components of highly ritualised elite activities such as processions and libations (Arte Situle 1961; Frey 1969). Although soon integrated into Venetic material culture, they were originally vessels of exotic origin with a widespread geographical distribution, from Continental Europe to Central Italy. Their employment at elite banquets highlights the 'international' rituality of alcohol consumption, whose role in promoting commensality, hospitality and power dynamics in late prehistory is well-acknowledged (e.g. Dietler 1990; Iaia 2005: 207-219; 2006; for Veneto see Perego $2010 ; 2012 a$ ). Not surprisingly, therefore, practices of ritual drinking are often represented on situla art objects, which allow us to glimpse the lost language of the ritualised gestures constituting the ritual banquet.

The diffusion of situlae in Veneto relates to the adoption by the local elites of sophisticated practices of consumption which often featured exotic components and were integrated into a larger spectrum of ritual technologies of status construction and expression. The same must have been true of other practices represented on situla art, and bearing strong elite overtones, such as hunting, weaving, sacrificing animals, playing games and conducting warfare. Notably, many 
artefacts usually appearing in Veneto in wealthy graves (e.g. axes, weaponry, weaving tools, and arrows) relate closely to these practices. Within the tomb, these items were also often accompanied by bronze banqueting equipment, situla art products and, more rarely and mainly from the late Iron Age, inscribed artefacts. As Riva (2010) argues for Orientalising Etruria, the introduction of new food technologies in the elite context is not only to be related to the creation of new modes of political negotiation via the ritual banquet, but also to the promotion of novel practices of embodiment which altered the construction and perception of the elite individual's self. As such, the specialised equipment for ritual food preparation and consumption may have acted as a metaphorical extension of the elite person him / herself while signalling group belonging (Perego 2012a). In Veneto, for example, the intimate relationship between the situla and the self was reinforced by the occasional adoption of the situla vessel shape for elite funerary urns. This close association of situlae with the elite body was taken even further through the practice of the anthopomorphisation of the urn, which has been identified so far only in the case of wealthy graves. This was achieved by wrapping the situla-urn in a cloth or dress and / or by embellishing it with ornaments and belts employed to re-create the lost integrity of the cremated body. Interestingly, this practice is also well-known from Etruscan and Centro-Italian funerary contexts (e.g. von Eles 2002), and may have been adopted by the Veneto elite alongside the other foreign practices described in this chapter.

\section{The Early Iron Age}

One of the earliest Este graves signalling the elaboration by prominent local groups of a shared ritual language in use until the $3^{\text {rd }}$ century is Ricovero tomb 236, a multiple grave of exceptional wealth and ritual complexity dating to the $8^{\text {th }}$ century (Iaia 2006; Chieco Bianchi and Calzavara Capuis 1985: 300-312). The most prestigious urn in the grave was a bronze situla either imported from Continental Europe or produced locally by imitating an exotic vessel shape. While the bones of the deceased have been lost, the weaponry possibly imported from the eastern Alpine region and the pins usually associated with male depositions indicate a male burial. The latter may have been accompanied by a female individual, as suggested by the presence inside the situla of ornaments generally associated with women. The second urn in the grave, a ceramic vessel, yielded rich female ornaments. Apart from weaponry, ornaments and pins, the bronze situla-urn contained a sympotic service for the preparation and distribution of an indeterminate beverage, possibly wine or beer. This sympotic equipment included two different handled containers probably employed to carry the main beverage (e.g. alcohol) and any additional components (e.g. water), while the three strainers might have been used to filter the residuals generally found in ancient fermented beverages. Finally, the high-handled cups were probably used to remove the liquid from the 'krater' - the larger vessel in which alcohol was mixed with water. The 'krater' was possibly represented in this case by the situla-urn itself. These sympotic implements bear evidence of burning and may have burnt with the dead. The deposition of a sympotic set on the pyre and later in the urn was an extremely rare practice at Este, where banqueting vessels were usually placed unburned in the grave outside the urn. The close connection between the sympotic set from tomb 236 and the dead buried in the bronze situla seems intended to reinforce the vessels' pertinence to the elite individual(s) buried here, who may have been in charge of the intoxicating beverage's preparation. The grave assemblage also included an exceptionally sophisticated ceramic drinking and dining set. Part of this service was found in the tomb container and part was placed intentionally broken on the tomb's covering slab. The ceramic drinking set included numerous high-handled cups possibly used by the deceased's fellow diners, either in their everyday life or during the funeral (Iaia 2006). The latter may have been allowed to drink, but not to manipulate the precious intoxicant - a prerogative 
possibly belonging to the person(s) buried in the situla-urn with the bronze set for beverage preparation and consumption. Two other implements interpreted as incense burners seem to recall practices of purification common at the Graeco-Etruscan banquet / symposium: their presence reinforces the idea that the Venetic elite were constructing their social identity in part through the adoption of foreign rituals.

Although pre-dating the spread of both situla art and writing in Veneto, Ricovero tomb 236 proves that the channels of cultural transmission were already established at this stage. The Venetic elites exhibited their openness towards non-local practices of consumption and their ability to adapt diverse cultural influences to their needs. The emphasis granted to the ingestion of sophisticated beverages, presumably alcohol, demonstrates that the ritual techniques of formal drinking later associated with situla art and writing were already a medium adopted to advertise the elites' status. Significantly, many of the ritual practices adopted in this grave remained in use at Este until the $3^{\text {rd }}$ century вс, often in tombs containing situla art and inscribed objects, as exemplified by the graves described below.

Benvenuti tombs 122, 124, and 126 were erected near each other between c.625 and 550 BC. These yielded grave goods bearing some of the most ancient and most sophisticated - in terms of compositional complexity - situla art objects from the Ricovero-Benvenuti cemetery. The exceptional wealth and close proximity of the tombs suggest they belonged to an elite group. The rare and exotic grave goods found within indicate that the tomb owners, or their living kin or associates, might have been able to monopolise the production and / or acquisition of prestigious bronze status symbols (Chieco Bianchi and Calzavara Capuis 2006: 46). The most ancient grave, Benvenuti 122, contained two urns dating to $c .625-600$ BC and probably belonging to women (Chieco Bianchi and Calzavara Capuis 2006: 267-276). The most ancient urn consisted of a bronze situla embellished with a complex decoration of dots, studs and stylised birds of Central European inspiration. This vessel was covered by a bronze drinking cup whose Central European geometric ornamentation is accompanied by vegetal and animal motifs in the manner of the earliest Bolognese situla art style. An influence from Etruria and Bologna is also visible in the luxurious ornaments from the urns. In the case of Benvenuti tomb 126, the famous Benvenuti situla was re-used as a container for a small ceramic urn containing the remains of a 1- to 3-year old child (Chieco Bianchi and Calzavara Capuis 2006: 320-331). The urn was adorned with luxurious ornaments and wrapped in a cloth giving the cinerary human-like qualities. The theme of drinking was evoked not only by the situla itself, but also by the scenes of ritual drinking embossed on the vase and described above. The presence of three high-handled cups in the tomb further emphasised this possible reference to alcohol consumption.

The third tomb of the group, Benvenuti 124, dates to c.550 вс (Chieco Bianchi and Calzavara Capuis 2006: 294-301) and yielded three ceramic urns with the remains of three adults and two children. One of the urns was placed inside a bronze situla, whose lid bore a situla art motif of animals and geometric dots. The grave also yielded a sophisticated bronze drinking set, two bone and bronze distaffs, rich ornaments, a knife from the Adriatic koinè and an axe. A bronze belt plaque and two fibulae were from Lombardy.

As for the earlier Ricovero tomb 236, these graves reveal a clear intersection of diverse cultural influences incorporated into the material culture and lifestyle of the Este elite. Drinking still features as a fundamental means of social promotion and self-expression, while situla art is adopted as a novel status symbol promoting new ways of elite self-representation. In the case of the Benvenuti situla, which featured images of aristocrats involved in socially distinctive activities, the impact of the new technology over the elite individual's self-perception must have been considerable. In a cultural context in which representations of human beings were possibly rare or absent at this early stage, the Benvenuti situla's owners, perhaps for the very first time, were able to ideally project themselves and their world on the new medium, like in a mirror. 


\section{From the $6^{\text {th }}$ Century to the Late Iron Age}

The production of elaborate situla art motifs on large bronze containers seems to vanish at Este during the $6^{\text {th }}$ century. This has been related to the social changes brought about by the incipient urbanisation, which may have altered the consumption habits of previous situla art commissioners or even wiped out the previous elite groups (Capuis 2001). At Este, this time-span was also characterised by the development of the first local sanctuaries as new loci of public display and political negotiation (Ruta Serafini 2002). It was at that moment that writing presumably appeared in Veneto as a novel technique of status expression, possibly favoured by the new protourban elites. The latter, however, also maintained older practices of status construction, including ritual drinking. Significantly, one of the most ancient Venetic inscriptions presently known was inscribed on a bronze cup of Etruscan form, the kantharos from Lozzo near Este (Locatelli and Marinetti 2002). Kantharoi were widely employed at the Etruscan elite banquet and exported. The Lozzo cup dates between $c .625-575$ BC although the inscription may have been added later. The area of discovery was occupied in Roman times by a sanctuary. The Venetic inscription is probably votive in nature, suggesting that a cult was already established at Lozzo during the Iron Age. The kantharos must have been a valuable item in many respects. Apart from the exceptional value attributed by the Este elite to bronze containers, its exoticism due to its Etruscan shape and its reference to privileged drinking practices relate it to prominent individuals. The emphasis granted to the donors through the inscription of their personal names on the vessel testifies of new forms of expressing the elite individuals' self and social role in a novel context of display - the sanctuary - via the novel technology of writing.

The Lozzo kantharos embodied a close relationship between three of the main aspects of the elite 'language' which I have sketched out so far, namely writing, drinking and the acquisition of exotica. A similar relationship between drinking, the adoption of foreign rituals and, in this case, situla art is evidenced by a belt plaque from Este Carceri tomb 48 (500-450 вС). This belt plaque features a single situla art scene which appears to reproduce the reclined symposium of GraecoEtruscan inspiration (Capuis and Chieco Bianchi 1992: 95): a woman wrapped in a veil is represented about to serve a man reclining on a couch. The ideology of the reclined symposium may have spread into Veneto from the $6^{\text {th }}-5^{\text {th }}$ century вс alongside the importation of Greek drinking vessel shapes and possibly wine. It is unclear, however, when and to what extent the Venetic elites came to imitate the complex ritual practices of the reclined Graeco-Etruscan symposium. This uncertainty is compounded by the extreme selectivity exhibited by the inhabitants of Veneto in the choice of imported vessel types, as they adopted only a restricted number of the whole range of sympotic vessels available in Greece and Etruria. The widespread deposition of local ware even within the wealthiest Venetic graves further suggests the persistence of localised modes of consumption. The ambivalent reaction of Venetic elites towards the new sympotic practice is revealed by the Carceri plaque itself, where the woman holds a jug clearly resembling an Etruscan schnabelkanne. This beaked jug shape - albeit widely attested in regions such as Etruria, Lombardy and Continental Europe - was extremely rare in Veneto. Jugs of any type remained uncommon here until the $3^{\text {rd }}$ century. Their rarity, set against the still widespread use of high-handled cups to serve beverages, further suggests the persistence of traditional drinking practices. It is significant, therefore, that in the case of the Carceri belt plaque a new and possibly uncommon ritual practice the reclined symposium featuring the employment of a rare vessel shape, the schnabelkanne - was related to a medium, situla art, whose distinctive social value has been already emphasised. These associations reinforce the special nature of both the practice and the medium and emphasise the sophistication of these privileged modes of self-expression.

It is also worth emphasising again the exceptional value attributed in Veneto to elaborate bronze belts and belt plaques, as both status symbols and ceremonial artefacts. Due to their social value 
and proximity to the body, belts probably constituted important vehicles for communicating an individual's elevated status, as testified by both their deposition in wealthy graves and their display in sanctuaries as prestigious miniature offerings or depictions on laminas (Capuis and Chieco Bianchi 1992: 84, 97). The importance of belts and belt-elements in the funerary context is emphasised by the wide range of ritual manipulations undergone by these artefacts, including deliberate fragmentation, burning, and deposition around the urn to promote the latter's identification with the elite body. Este Nazari tomb 161 (400-350 вC) provides an example of this kind of ritual (Tirelli 1981). In this wealthy grave, two bronze situlae contained a ceramic urn each. The largest situla was wrapped in cloth. A lozenge-shaped belt decorated with situla art motifs was fastened around this vessel, apparently to give human-like qualities to the urn-container. This deposition emphasises again the symbolic link elaborated over the centuries between situla art itself, sophisticated practices of 'humanisation' of the urn and the employment of situlae as urns in elite graves. The grave also yielded a rich service for drinking and for food preparation, including meat roasting. This emphasis on the preparation of solid foodstuff via the deposition of roasting spits, firedogs, knives and slices is characteristic of wealthy graves from the $4^{\text {th }}$ century and suggests the spread of new elite habits of display and consumption. Not surprisingly, the interment of these implements was often accompanied by the deposition of situla art objects and inscribed vessels (e.g. Capuis and Chieco Bianchi 1992: 86-87).

Evidence enabling the clearest synthesis of the ritual practices described above is offered by finds unearthed in Ricovero tomb 23/1984, 300-250 вс (Chieco Bianchi 1987). This grave of exceptional wealth displays both an intentional ritual conservatism going back to the $8^{\text {th }}$ century and an extraordinary openness towards contemporaneous cultural influences especially from Etruria and the international port-of-trade of Adria, located on the Adriatic Sea slightly south of the main Venetic area. The urn found in the grave was a skyphos containing the remains of an unsexed individual. The skyphos was placed within a bronze situla incised with the name of the deceased, a woman called Nerka Trostiaia. The situla was also wrapped in cloth embellished with rich ornaments probably pinned or sewn on it, again intended to evoke the human body. The importance of alcohol consumption was also emphasised via the deposition of an extremely rich banqueting set at the bottom of the grave, which included several imported items. An Attic redfigure krater was found broken on the tomb's covering slab, possibly indicating the continuation of a ritual practice that is already attested 500 years earlier in Ricovero tomb 236. Importantly, this grave featured the latest example of situla art presently known at Este, the bronze model of a piece of furniture decorated with animal images.

\section{Mutually Exclusive Spheres?}

It is noteworthy that in Veneto, despite the adoption of writing and situla art within the same social milieu and often in connection with exotica, foreign ritual practices and sympotic rituals, inscriptions have never been found to date on objects bearing situla art. This is true for the vast majority of the entire situla art corpus presently known, with only a couple of exceptions (Zaghetto 2007: 180). An obvious explanation for this pattern is that situla art and writing were different communicative systems. The former was a non-linguistic symbol-based system spread over a vast area inhabited by different ethnic groups and possibly developed to facilitate interaction between people unable to speak the same language. The latter was the written form of languages (e.g. Venetic) presumably spoken in the more restricted area where the related inscriptions have emerged. This important observation, however, does not explain why the receivers / owners of situla art items, who may have been exposed to, or even taken control of, writing as well, decided not to inscribe their possessions (or have them inscribed), for example in giftexchange with people speaking the same language or at the funeral, by putting the deceased's name on a decorated situla-urn. For the Veneto, this 'otherness' between the two 'languages' seems 
compounded by the fact that the interment of both written items and situla art objects in the same grave seems to have been uncommon, with some exceptions such as Nerka's tomb. As suggested by Whitehouse (pers. comm.), a possible explanation is that few Venetic inhabitants were 'bilingual' in the two 'languages'. It is worth noting, however, that this pattern may partially relate to the limited number of intact wealthy graves dating between the $5^{\text {th }}$ and $3^{\text {rd }}$ centuries BC. It is also possible that inscriptions were written on perishable materials now vanished. Another possible explanation for this pattern, however, may reside in the uses to which writing was put after its introduction in Veneto. Although writing may have spread in Veneto as early as the late $7^{\text {th }}$ or $6^{\text {th }}$ century $\mathrm{BC}$, at Este the presence of inscriptions inside the grave (i.e. the context in which situla art items are found) is extremely rare before the late $4^{\text {th }}$ - early $3^{\text {rd }}$ century BC. One possible exception is a male name inscribed on a bronze tripod or cup buried in a grave dating to the $5^{\text {th }}$ or $4^{\text {th }}$ century вс (Marinetti 1992: 138). The practice of inscribing the deceased's name on urns started in the $3^{\text {rd }}$ century and became more common in the following centuries, especially from $c .75-25$ BC. The epitaph inscribed on Nerka's situla is one of the earliest examples of this practice. A similar epitaph is incised on a contemporary situla-urn buried in a wealthy multiple grave, namely Benvenuti tomb 123 (Chieco Bianchi and Calzavara Capuis 2006: 276-294). This tomb yielded several items comparable with Nerka's grave goods, including lavish ornaments, a bronze model of a loom, three axes and a skyphos. Again, the inscribed situla-urn was possibly wrapped in a cloth. Interestingly, no situla art product comes from this grave, although this may relate to the several re-openings the tomb underwent.

Before 325-300 BC writing was generally adopted in cemetery contexts to mark the gravestones ascribing the ownership of tombs and / or burial plots to prestigious individuals and families. The individuals mentioned on tombstones were $75 \%$ male. In the mortuary context, therefore, writing was mainly associated with the male individual and the monumentality, visibility and durability of funerary monuments erected outside the grave. A possible shift in the function and values accorded to writing may have taken place around $300 \mathrm{BC}$ with the spread of 'hidden' and more intimate dedications on small, portable items buried in the grave, such as urns and vessels which bore male and female names in a similar proportion. Inscriptions on small objects were not unknown at Este before, but mainly appeared on votive offerings dedicated in sanctuaries, entailing different ways of constructing and expressing personal and social identities. This shift towards a 'hidden' funerary literacy took place when situla art seems to disappear. The deposition of situla art products and written objects in the same grave was therefore limited to c.325-250 BC, when the two 'languages' were briefly in use in the same context at the same time. Later, the progressive erosion of the previous prominent groups' social identity in favour of novel forms of display and consumption probably led to the disappearance of situla art - a language which had lost its significance in the new social setting. Before $c .325$, I cannot exclude the possibility that writing and situla art were used contemporaneously in the same context outside the grave. However, it seems that, despite their common pertinence to the elite 'language' outlined above, their final destination was different, and entailed a diverse conceptualisation of the two media, due to complex social motivations which are not presently identifiable.

\section{Conclusion}

By drawing on (a) Zaghetto's interpretation of situla art as a sophisticated communication system, (b) recent developments in sociolinguists breaking down the division between iconic and verbal literacies and (c) Street's understanding of literacy as an ideological practice whose nature is contextdependent and power-laden, this chapter discussed the reciprocal interplay between Venetic writing and iconography at Iron Age Este, with an emphasis on their material dimension and their role in elite consumption practices. Both writing and situla art were most likely adopted from non-local 
contexts by Venetic privileged groups in order to enhance their social prominence and advertise their access to exotic goods and knowledge of rituals and ideas attested in foreign regions. Hence, I outlined a preliminary account of the intricate relationship between writing, situla art and other means of status expression adopted by the Este elite, such as formal drinking. This relationship suggests that - when considered in the perspective adopted in this chapter - the conventional scholarly habit of studying situla art and writing as unrelated phenomena taken outside their similar social milieu of development is less persuasive. By contrast, the Este elites were able to elaborate a complex hybrid language, flexible but partially stable over time, which was probably adopted to advertise the social prominence and affiliation of its recipients and creators. The adoption of foreign modes of status enhancement and consumption as well as the continuous re-elaboration and transmission of the entire 'package' may have promoted changes in bodily practices and forms of self-perception and self-representation of the elite person him / herself. Both situla art and writing were part of the 'package' and their importance in 'creating' Este elite individuals cannot be underestimated.

\section{Acknowledgements}

I want to warmly thank Ruth Whitehouse, Kathryn Piquette and the anonymous reviewers for their comments upon earlier versions of this paper.

\section{References}

Arte Situle 1961. Arte delle Situle dal Po al Danubio: Exhibition Catalogue. Firenze: Sansoni.

Balista, C. and Ruta Serafini, A. 1992. Este Preromana: Nuovi dati sulle necropoli. In Tosi, G. (ed.), Este Antica dalla Preistoria all'Età Romana. Este: Zielo, 109-123.

Barton, D. and Hamilton, M. 1998. Local Literacies: A study of reading and writing in one community. London: Routledge.

Bianchin Citton, E., Gambacurta, G. and Ruta Serafini, A. (eds) 1998. ...Presso l'Adige Ridente... Recenti Rivenimenti Archeologici da Este a Montagnana. Padova: ADLE.

Buckingham, D. 1993. Towards New Literacies: Information technology, English and media education. The English and Media Magazine Summer: 20-25.

Capuis, L. 2001. L’Arte delle Situle Quarant’anni Dopo. Arheološki Vestnik 52: 199-205.

Capuis, L. 2009. I Veneti: Civiltà e cultura di un popolo dell'Italia Preromana ( $3^{\text {rd }}$ edition revised). Milano: Longanesi.

Capuis, L. and Chieco Bianchi, A. M. 1992. Este Preromana: Vita e cultura. In Tosi, G. (ed.), Este Antica dalla Preistoria all'Età Romana. Este: Zielo, 41-108.

Chieco Bianchi, A. M. 1987. Dati Preliminari su Alcune Tombe di III Secolo da Este. In Vitali, D. (ed.), Celti ed Etruschi nell'Italia Centro-Settentrionale dal V Secolo a.C alla Romanizzazione: Atti del Colloquio Internazionale. Bologna 12-14 Aprile 1985. Imola: Bologna University Press, 191-236.

Chieco Bianchi, A. M. and Calzavara Capuis, L. 1985. Le Necropoli di Casa di Ricovero, Casa Muletti Prosdocimi, Casa Alfonsi. Roma: Giorgio Bretschneider Editore.

Chieco Bianchi, A. M. and Calzavara Capuis, L. (eds) 2006. La Necropoli di Villa Benvenuti. Roma: Giorgio Bretschneider Editore.

Coiro, J., Knobel, M., Lankshear, C. and Leu, D. J. (eds) 2008. Handbook of New Literacies Research. New York: Lawrence Erlbaum Associates.

Colonna, G. 1980. Rapporti Artistici tra il Mondo Paleoveneto e il Mondo Etrusco. In Este e la Civiltà Paleoveneta a Cento Anni dalle Prime Scoperte: Atti dell'XI Convegno di Studi Etruschi e Italici, Este, Padova, 27 Giugno-1 Luglio 1976. Firenze: L. S. Olschki, 177-190.

Cornell, T. J. 1991. The Tyranny of the Evidence: A discussion of the possible uses of writing in Etruria and Latium in the Archaic Age. In Literacy in the Roman World (Journal of Roman 
Archaeology Supplementary Series 3). Ann Arbor, MI: Department of Classical Studies, University of Michigan, 7-343.

Cresci Marrone, G. and Tirelli, T. (eds) 2009. Altnoi. Il Santuario Altinate: Strutture del Sacro a Confronto e i Luoghi di Culto lungo la Via Annia. Atti del Convegno. Venezia 4-6 Dicembre 2006. Rome: Quasar.

Cuscito, G. (ed.) 2009. Aspetti e Problemi della Romanizzazione: Venetia, Histria e Arco Alpino Orientale. Trieste: Editreg Sass.

Dietler, M. 1990. Driven by Drink: The role of drinking in the political economy and the case of Iron Age France. Journal of Anthropological Archaeology 9(4): 352-406. http://dx.doi. org/10.1016/0278-4165(90)90011-2

Di Filippo Balestrazzi, E. 1967. Rapporti iconografici di alcuni monumenti dell'arte delle situle: Materiali per uno studio delle trasmissioni figurative. Venetia 1: 97-200.

Di Filippo Balestrazzi, E. 1980. Nuovi confronti iconografici e un'ipotesi sui rapporti tra l'area delle situle e il mondo orientale. In Este e la Civiltà Paleoveneta a Cento Anni dalle Prime Scoperte: Atti dell'XI Convegno di Studi Etruschi e Italici, Este, Padova, 27 Giugno-1 Luglio 1976. Firenze: L. S. Olschki, 153-170.

Fogolari, G. and Gambacurta, G. (eds) 2001. Materiali Veneti e Romani del Santuario di Lagole di Calalzo al Museo di Pieve di Cadore. Rome: Giorgio Bretschneider Editore.

Frey, O-H. 1969. Die Entstehung der Situlenkunst: Studien zur Figurlich Verzieten Toreutik von Este (Romisch-Germanische 31). Berlin: De Gruyter.

Gamba, M., Gambacurta, G., Ruta Serafini, A., Tiné, V. and Veronese, F. (eds) 2013. Venetkens: Viaggio nella terra dei veneti antichi. Venezia: Marsilio.

Gambacurta, G. 2003. Il Venetorum Angulus e la Pressione Celtica (IV-III Secolo a.C.). In Malnati, L. and Gamba, M. (eds), I Veneti dai Bei Cavalli. Treviso: Canova, 81-92.

Gangemi, G. 2008. Dinamiche Insediative nel Bellunese. Età Preromana: Aggiornamenti. In I Veneti Antichi. Novità e Aggiornamenti. Atti del Convegno di Studio. Isola della Scala, 15 Ottobre 2005. Sommacampagna: Cierre Edizioni, 139-153.

Gee, J. P. 2008. What Video Games Have to Teach Us About Learning and Literacy (revised and updated). Basingstoke: Palgrave Macmillan.

Iaia, C. 2005. Produzioni Toreutiche della Prima Età del Ferro in Italia Centro-Settentrionale: Stili decorativi, circolazione, significato. Pisa: Editoriali e Poligrafici Internazionali.

Iaia, C. 2006. Servizi Cerimoniali da 'Simposio' in Bronzo del Primo Ferro in Italia Centro-Settentrionale. In von Eles, P. (ed.), La Ritualità Funeraria tra Età del Ferro e Orientalizzante in Italia. Atti del Convegno. Verrucchio, 26-27 Giugno 2002. Pisa: Istituti Editoriali e Poligrafici Internazionali, 103-110.

Kress, G. 2003. Literacy in the New Media Age. London: Routledge. http://dx.doi. org/10.4324/9780203164754

Locatelli, D. and Marinetti, A. 2002. La Coppa dello Scolo di Lozzo. In Ruta Serafini, A. (ed.), Este Preromana: Una città e i suoi santuari. Este: Zielo, 201-202.

Lomas, K. 2007. Writing Boundaries: Literacy and identity in the ancient Veneto. In Lomas, K., Whitehouse, R. and Wilkins, J. (eds), Literacy and the State in the Ancient Mediterranean. London: Accordia Research Institute, 149-169.

Lucke, W. and Frey, O-H. 1962. Die Situla in Providence (Rhode Island). Berlin: De Gruyter.

Marinetti, A. 1992. Epigrafia e Lingua di Este Preromana. In Tosi, G. (ed.), Este Antica dalla Preistoria all'Età Romana. Este: Zielo, 125-172.

Marinetti, A. 1999. Venetico 1976-1996. Acquisizioni e Prospettive. In Paoletti, O. (ed.), Protostoria e Storia del 'Venetorum Angulus': Atti del XX Convegno Internazionale di Studi Etruschi e Italici. Portogruaro (Ve), Quarto d'Altino (Ve), Este (Pd), Adria (Ro). 16-19 Ottobre 1996. Firenze: L. S. Olschki, 391-436.

Marinetti, A. 2004. Venetico: Rassegna di Nuove Iscrizioni (Este, Altino, Auronzo, S. Vito, Asolo). Studi Etruschi 70: 389-408. 
Marinetti, A. 2008. Lo Stato Attuale dell'Epigrafia Venetica. Quaderni di Archeologia del Veneto 25: 189-193.

Messaris, P. 1994. Visual Literacy: Image, mind and reality. Boulder: Westview Press.

Messaris, P. 1997. Visual Persuasion: The role of images in advertising. Thousand Oaks: Sage Publications.

Messaris, P. and Moriarty, S. 2005. Visual Literacy Theory. In Smith, K., Moriarty, S., Barbatsis, G. and Kenney, K. (eds), Handbook of Visual Communication. Mahwah: Lawrence Erlbaum Associates, Publishers, 481-502.

Pellegrini, G. B. and Prosdocimi, A. 1967. La Lingua Venetica. Padova: Zielo.

Perego, E. 2010. Osservazioni Preliminari sul Banchetto Funerario Rituale nel Veneto Preromano: Acquisizione, Innovazione e Resistenza Culturale. In Mata Parreño, C., Pérez Jordà, G. and Vives-Ferrándiz Sánchez, J. (eds), De la Cuina a la Taula: IV Reunió d'Economia en el Primer Millenni a.C. Saguntum (Papeles del Laboratorio de Arqueología de València, Extra 9). València: Universitat de València, 287-294.

Perego, E. 2012a. The Construction of Personhood in Veneto (Italy) Between the Late Bronze Age and the Early Roman Period. Unpublished PhD dissertation, University College London.

Perego, E. 2012b. Family Relationships in Late Bronze Age, Iron Age and Early Roman Veneto (Italy): Preliminary considerations on the basis of osteological analysis and epigraphy. In Lawrence, R. and Stromberg, A. (eds), Families in the Greco-Roman World. London: Continuum, $121-142$.

Prosdocimi, A. L. 1988. La Lingua. In Fogolari, G. and Prosdocimi, A. L. (eds), Este Preromana. Lingua e Cultura. Padova: Programma, 225-420.

Prosdocimi, A. L. 2002. Veneti, Eneti, Euganei, Ateste: I nomi. In Ruta Serafini, A. (ed.), Este Preromana: Una Città e i Suoi Santuari. Treviso: Canova, 45-76.

Riva, C. 2010. The Urbanisation of Etruria: Funerary practices and social change, c.700-600 BC. Cambridge: Cambridge University Press.

Ruta Serafini, A. (ed.) 2002. Este Preromana. Una città e i suoi santuari. Treviso: Canova.

Selber, S. 2004. Multiliteracies for a Digital Age. Carbondale: Southern Illinois University Press.

Stoddart, S. and Whitley, J. 1988. The Social Context of Literacy in Archaic Greek and Etruria. Antiquity 62: 761-772.

Street, B. V. 1984. Literacy in Theory and Practice. Cambridge: Cambridge University Press.

Tirelli, M. 1981. Una Nuova Lettura della Tomba Nazari 161 di Este (Padova). Archeologia Veneta 4: 7-28.

von Eles, P. (ed.) 2002. Guerriero e Sacerdote: Autorità e comunità nell'Età del Ferro a Verucchio. La Tomba del Trono. Firenze: All'Insegna del Giglio.

Whitehouse, R. and Wilkins, J. 2006. Veneti and Etruscans: Issues of language, literacy and learning. In Herring E., Lemos, I., Lo Schiavo F., Vagnetti, L., Whitehouse, R. and Wilkins, J. (eds), Across Frontiers: Papers in honour of David Ridgeway and Francesca R. Serra Ridgeway. London: Accordia Research Institute, 531-548.

Zaghetto, L. 2002. Dalla 'Parola' alle 'Frasi': Unità semplici e unità strutturate nel linguaggio delle immagini. Il caso dell'arte delle situle. In Colpo, I., Favaretto, I. and Ghedini, F. (eds), Iconografia 2001: Studi sull'immagine. Rome: Quasar, 31-43.

Zaghetto, L. 2006. La Ritualità nella Prima Arte delle Situle. In von Eles, P. (ed.), La Ritualità Funeraria tra Età del Ferro e Orientalizzante in Italia: Atti del Convegno. Verrucchio 26-27 Giugno 2002. Pisa: Istituti Editoriali e Poligrafici Internazionali, 41-45.

Zaghetto, L. 2007. Iconography and Language: The missing link. In Lomas, K., Whitehouse, R. and Wilkins, J. (eds), Literacy and the State in the Ancient Mediterranean. London: Accordia Research Institute, 171-181. 